\title{
Hubungan Antara Tekanan Darah Dan Fungsi Ginjal Pada Preeklamsi di RSUP DR. M. Djamil
}

\author{
Ilhami Fadhila ${ }^{1}$, Rahmatina B Herman ${ }^{2}$, Yusrawati $^{3}$
}

\begin{abstract}
Abstrak
Preeklamsi merupakan komplikasi dalam kehamilan yang dapat menyebabkan mortalitas dan morbiditas bagi ibu dan janin. Angka kejadian preeklamsi terus meningkat dari tahun ketahun. Di Sumatera Barat insidennya menduduki posisi kedua setelah perdarahan. Tujuan penelitian adalah menentukan hubungan antara tekanan darah dan fungsi ginjal pada preeklamsi. Penelitian ini bersifat rancangan cross sectional yang dilakukan dari Juni 2015 sampai Juli 2015. Metode pengambilan sampel adalah dengan menggunakan data sekunder sebanyak 33 ibu hamil preeklamsi di RSUP Dr. M. Djamil Padang. Analisis statistik yang digunakan adalah uji korelasi pearson dan spearman. Hasil analisis menunjukan semua variabel memiliki $p>0,05$. Hal ini berarti bahwa tidak terdapat hubungan bermakna antara tekanan darah sistolik dengan kreatinin $(r=-0,02, p=0,92)$ dan urea $(r=0,01, p=0,96)$ serta tekanan darah diastolik dengan kreatinin $(r=-0,01, p=0,94)$ dan urea $(r=-0,00, p=0,98)$. Simpulan penelitian ini adalah tidak terdapat hubungan bermakna tekanan darah dengan fungsi ginjal pada preeklamsi.
\end{abstract}

Kata kunci: preeklamsi, tekanan darah, kreatinin, urea

\begin{abstract}
Preeclampsia is a complication in pregnancy that can cause mortality and morbidity for mother and fetus. preeclampsia can lead to changes in multiple organ systems, including the kidneys. The incidence of preeclampsia has increased from year to year. In West Sumatra, the incident came second after bleeding. The objective of this study was to determine the relationship between blood pressure and kidney function in preeclampsia. This research was a cross sectional study conducted in June 2015 until July 2015. The secondary data as much as 33 preeclampsia pregnant women in Hospital Dr. M. Djamil Padang. The statistical analysis used Pearson and Spearman correlation test. The result was all variables have $p$-value $>0,05$. There no significant relationship between sistole blood pressure and creatinine $(r=-0,02, p=0,92)$ and urea $(r=0,01, p=0,96)$. No significant between diastole blood presure and creatinine $(r=-0,01, p=0,94)$ and urea $(r=-0,00, p=0,98)$. The conclusion is a statistically insignificant between blood pressure and function of kidney in preeclampsia
\end{abstract}

Keywords: preeclampsia, blood pressure, creatinine, urea

Affiliasi penulis: 1. Prodi Pendidikan Dokter Fakultas Kedokteran Universitas Andalas Padang (FK Unand), 2. Bagian Fisiologi FK Unand, 3. Bagian Obstetri dan Ginekologi FK Unand.

Korespondensi: Ilhami fadhila, Email: ilhamifadhila@yahoo.com Telp: 085278783363

\section{PENDAHULUAN}

Setiap tahun sekitar 160 juta perempuan di seluruh dunia hamil. Sebagian besar kehamilan ini berlangsung dengan aman. Sekitar $15 \%$ menderita komplikasi berat dengan sepertiganya komplikasi yang mengancam jiwa. ${ }^{1}$ Hipertensi dalam kehamilan merupakan 5-15 \% penyulit kehamilan dan merupakan satu dari tiga penyebab tertinggi mortalitas dan morbiditas ibu bersalin. ${ }^{2}$ Menurut data UNICEF, pada tahun 2013 terdapat 289.000 kematian maternal dimana hipertensi dalam kehamilan menyumbang $14 \%$ dari jumlah total kematian didunia. ${ }^{3}$ 
Hipertensi dalam kehamilan mempengaruhi 5$10 \%$ dari seluruh kehamilan didunia. ${ }^{4}$ Dari seluruh ibu yang mengalami hipertensi selama masa hamil, setengah sampai dua pertiganya di diagnosis mengalami preeklamsi atau eklamsi. ${ }^{5}$

Di seluruh dunia, wanita yang mengalami preeklamsi sekitar 4-6\%. ${ }^{6}$ Di negara berkembang, dilaporkan angka kejadian berkisar antara 1,8\% sampai $16,7 \%$, sedangkan di negara maju angka kejadian lebih kecil yakni $0,4 \%{ }^{7}$ Kejadian preeklamsi di Amerika Serikat meningkat dari 2,5\% pada tahun 1987 menjadi $3,2 \%$ pada tahun $2004{ }^{8}$

Di Indonesia, kematian ibu yang disebabkan hipertensi dalam kehamilan sebanyak $23 \% .{ }^{9}$ Kejadian preeklamsi memberikan kontribusi pada kematian ibu. ${ }^{10}$ Berdasarkan data Dinas Kesehatan Provinsi Sumatera Barat, jumlah kematian ibu sebanyak 90 kasus, diantaranya disebabkan oleh perdarahan 39 kasus, preeklamsi/eklamsi 16 kasus, infeksi 7 kasus, partus macet 1 kasus dan 127 kasus lain. ${ }^{11}$

Preeklamsi merupakan sindrom spesifik kehamilan berupa hipertensi yang disertai proteinuria. Kedua gejala tersebut merupakan gejala yang paling penting dalam menegakkan diagnosis preeklamsi. Hipertensi ialah apabila tekanan darah lebih dari sama dengan 140/90 $\mathrm{mmHg}$ setelah gestasi 20 minggu dan proteinuria yaitu terdapatnya protein dalam urin lebih dari sama dengan $300 \mathrm{mg}$ per 24 jam atau urin dipstik lebih dari sama dengan +1 . Proteinuria ini tidak lagi sebagai penanda dari sindroma preeklamsi ${ }^{2,12,13}$

Preeklamsi mengakibatkan perubahan pada beberapa sistem dan organ tidak terkecuali pada organ ginjal. Secara umum preeklamsi menyebabkan terganggunya fungsi ginjal, baik di prerenal ataupun di renal. Pada preeklamsi terjadi vasokontriksi, yang mengakibatkan terjadinya penurunan aliran darah ke ginjal, sehingga Laju Filtrasi Glomerulus (LFG) menurun dan laju ekskresi kreatinin dan urea juga menurun. Selain itu, pada bagian renal terjadi perubahan parenkim ginjal, mengalami pembesaran glomerulus yang diikuti dengan pembengkakan sel endotel dan hilangnya fenestra endotel glomerulus (glomerular capillary endotheliosis). Kedua hal tersebut akan mengakibatkan terjadinya akumulasi kreatinin dan urea dalam cairan tubuh dan meningkatkan konsentrasinya dalam plasma. ${ }^{2,14,15,16}$

Ginjal memiliki fungsi bermacam-macam termasuk filtrasi glomerulus, reabsorbsi dan sekresi tubulus, pengenceran dan pemekatan urin, pengasaman urin, serta memproduksi dan memetabolisme hormon. Untuk mengetahui fungsi ginjal, parameter penilaiannya adalah dengan menilai ILFG dan kemampuan ekskresi. Zat yang secara klinis dapat dijadikan kriteria adalah kreatinin dan urea. $^{16,17}$

Penelitian sebelumnya mengenai preeklamsi, terbukti adanya peningkatan kadar kreatinin dan urea. Kadar kreatinin meningkat secara signifikan sebesar $24 \%$ dan kadar urea meningkat sebesar $6 \%{ }^{18}$ Penelitian lainnya juga membuktikan terjadi peningkatan kadar kreatinin dan urea bila dibandingankan dengan ibu yang hamil normal. ${ }^{19}$

Survei pendahuluan pada data rekam medis RSUP Dr. M. Djamil tercatat jumlah penderita preeklamsi dalam 3 tahun terakhir semakin meningkat yakni: pada tahun 2011 terdapat 137 kasus, tahun 2012 terdapat 158 kasus dan pada tahun 2013 terdapat 211 kasus. ${ }^{20}$

Berdasarkan uraian di atas, maka perlu untuk diteliti tentang hubungan tekanan darah dengan fungsi ginjal pada preeklamsi di RSUP Dr. M. Djamil Padang tahun 2013

\section{METODE}

Penelitian cross sectional ini telah dilakukan di bagian rekam medik RSUP DR. M. Djamil Padang. Penelitian dilaksanakan pada bulan Juni 2015 sampa Juli 2015. Sampel adalah data ibu yang menderita preeklamsi di bagian obstetrik dan ginekologi RSUP Dr. M. Djamil padang yang telah ditentukan berdasarkan rumus besar sampel penelitian analitik korelatif sebanyak 33 
HASIL

Berdasarkan penelitian yang telah dilakukan didapatkan hasil sebagai berikut.

Tabel 1. Rerata karakterisktik subjek dan variabel penelitian di RSUP Dr. M. Djamil Padang

\begin{tabular}{lrr}
\hline Parameter & \multicolumn{1}{c}{ Rerata } & \multicolumn{1}{c}{$\mathbf{I S D}$} \\
\hline Usia (tahun) & 30,03 & 6,81 \\
Paritas & 0,61 & 0,93 \\
Usia kehamilan (minggu) & 36,12 & 4,24 \\
TDS (mmHg) & 171,52 & 15,44 \\
TDD (mmHg) & 107,58 & 12,00 \\
Urea (mg/dL) & 27,36 & 13,00 \\
Kreatinin (mg/dL) & 0,97 & 0,38
\end{tabular}

Tabel 2. Hubungan tekanan darah sistolik dan diastolik dengan urea plasma dan kreatinin plasma di RSUP Dr. M. Djamil Padang

\begin{tabular}{lccrc}
\hline & \multicolumn{2}{c}{ TDS } & \multicolumn{2}{c}{ TDD } \\
\cline { 2 - 5 } & $\boldsymbol{r}$ & $\boldsymbol{p}$ & $\boldsymbol{r}$ & $\boldsymbol{p}$ \\
\hline Urea & 0,01 & 0,96 & $-0,00$ & 0,98 \\
Kreatinin & $-0,02$ & 0,92 & $-0,01$ & 0,94 \\
\hline
\end{tabular}

Hasil analisa statistik dengan uji korelasi (r) menunjukkan kekuatan hubungan yang sangat lemah antara tekanan darah dengan urea dan kreatinin. Hasil uji statistik menunjukan $p>0,05$ yang berarti bahwa tidak terdapat hubungan bermakna antara tekanan darah dengan urea dan kreatinin.

\section{PEMBAHASAN}

\section{Karakteristik Subjek Penelitian Usia}

Usia yang dianjurkan untuk hamil antara 20-35 tahun, karena kehamilan di bawah 20 tahun dan di atas 35 tahun merupakan kehamilan berisiko tinggi. Dalam penelitian ini didapat hasil bahwa rerata usia ibu hamil preeklamsi di RSUP DR. M, Djamil Padang adalah $30,03 \pm 6,81$ tahun. Hal ini sejalan dengan penelitian yang dilakukan oleh Lai et al (2012), di mana didapatkan rerata usia ibu adalah $31,58 \pm 6,2$ tahun. $^{21}$
Berdasarkan hasil penelitian disimpulkan bahwa usia ibu hamil preeklamsi di RSUP Dr. M. Djamil Padang tergolong ke dalam usia yang aman untuk hamil. Hal ini disebabkan karena tingkat pendidikan dan pekerjaan ibu yang baik sehingga saat ini sudah jarang menikah diusia muda.

\section{Paritas}

Faktor kehamilan pertama mempunyai risiko untuk terjadinya preeklamsi. Pada penelitian ini didapatkan rerata paritas adalah $0,61 \pm 0,93$. Hal ini sejalan dengan penelitian yang dilakukan oleh Nosrat (2011), bahwa rerata paritas ibu hamil preeklamsi adalah $0,97 \pm 1,21$. Berdasarkan hasil penelitian dapat disimpulkan bahwa paritas ibu hamil preeklamsi di RSUP Dr. M. Djamil Padang adalah primigravida.

\section{Usia Kehamilan}

Preeklamsi merupakan hipertensi dalam kehamilan yang terjadi setelah usia kehamilan 20 minggu yang disertai dengan atau tidaknya proteinuria. Berdasarkan waktu munculnya pereklamsi dibagi atas pereklamsi onset dini yaitu pada usia kehamilan < 34 minggu dan preeklamsi onset lambat yaitu $\geq 34$ minggu.

Pada penelitian ini didapatkan rerata usia kehamilan ibu adalah $36,12 \pm 4,24$. Hal ini didukung dengan penelitian yang dilakukan Manjareeka dan Nanda (2013), didapatkan hasil rerata usia kehamilan ibu adalah $34,40 \pm 2,98 .^{18}$ Berdasarkan hasil penelitian, dapat disimpulkan bahwa usia kehamilan pada ibu preeklamsi di RSUP Dr. M. Djamil padang berada pada trimester ketiga kehamilan dan tergolong ke dalam preeklamsi onset lambat $\geq 34$ minggu.

Urea

Pada penelitian ini didapatkan hasil rerata kadar urea plasma pada preeklamsi di RSUP Dr. M. Djamil Padang adalah 27,36 $\pm 13,00$. Hasil ini sejalan dengan penelitian yang dilakukan oleh Manjareeka (2013) yaitu $28.07 \pm 4,97 .^{18}$ Manjareeka dan Nanda juga mengatakan bahwa tidak terjadi peningkatan 
kadar urea yang signifikan antara ibu preeklamsi dengan ibu normotensi. ${ }^{18}$

Nilai rujukan urea adalah $24-49 \mathrm{mg} / \mathrm{dL}^{22} \mathrm{Di}$ RSUP Dr. M. Djamil Padang, nilai rujukan urea adalah 15-40 mg/dL. Berdasarkan hasil penelitian, dapat disimpulkan bahwa nilai kreatinin plasma masih dalam batas normal.

\section{Kreatinin}

Dalam penelitian ini, diperoleh hasil rerata kadar kreatinin plasma pada preeklamsi di RSUP Dr. M. Djamil Padang adalah $0,97 \pm 0,38$. Hasil ini sejalan dengan penelitian yang dilakukan oleh Manjareeka dan Nanda (2013) yaitu 0,72 $\pm 0,39 .^{18}$

Nilai rujukan kreatinin adalah 0,6 - 1,3 $\mathrm{mg} / \mathrm{dL}^{23}$. Sementara itu, di RSUP Dr. M. Djamil Padang, nilai rujukan kreatinin adalah 0,6 - 1,2 $\mathrm{mg} / \mathrm{dL}$. Berdasarkan hasil penelitian, dapat disimpulkan bahwa nilai kreatinin plasma masih dalam batas normal.

\section{Hubungan Tekanan Darah dengan Fungsi Ginjal Pada Preeklamsi}

Preeklamsi terjadi akibat kegagalan kegagalan dari invasi sel sitostrofoblas pada arteri spiralis, sehingga arteri spiralis tetap kaku dan menyebabkan terjadinya iskemia plasenta. Iskemia plasenta akan memicu terjadinya disfungsi endotel, yang bisa menganggu fungsi ginjal dan berdampak terhadap peningkatan kadar urea dan kreatinin.

Penelitian yang dilakukan Jumaah (2012), mendukung bahwa preeklamsi akan berpengaruh terhadap fungsi ginjal. ${ }^{19}$ Jumaah melaporkan bahwa pada preeklamsi terjadi peningkatan kadar kreatinin dan urea $(88,8 \pm 12,49 \mu \mathrm{mol} / \mathrm{l} ; 4,72 \pm 1,01 \mathrm{mmol} / \mathrm{L})$ dibandingkan dengan ibu normal $(56,61 \pm 8,2) \mu \mathrm{mol} / \mathrm{l}$; $2,48 \pm 0,62 \mathrm{mmol} / \mathrm{L}$ ) serta secara statistik didapat nilai $\mathrm{p}<0,05^{19}$

Pada penelitian ini didapatkan bahwa tidak terdapat hubungan yang bermakna. Pada penelitian ini didapatkan hasil bahwa hubungan tekanan darah sistolik dan diastolik dengan urea menunjukan kekuatan hubungan yang sangat lemah dan tidak terdapat hubungan yang bermakna $(p>0,05)$ dengan nilai adalah $r=0,01, p=0,96$ dan $r=-0,00, p=0,98$.
Hubungan tekanan darah sistolik dan diastolik dengan kreatinin pada penelitian ini juga menunjukan kekuatan hubungan yang sangat lemah dan secara statistik semua hubungan tidak ada yang bermakna ( $p>0,05)$, dengan nilai korelasi adalah $r=-0,02$, $p=0,92$ dan $r=-0,01, p=0,94$.

Hal ini sejalan oleh penelitian yang dilakukan Wiyono (2013) yang mengatakan bahwa tidak ada perbedaan yang signifikan antara kadar urea pada ibu lahir normal dengan preeklamsi $(p=0,68){ }^{24}$

Penelitian yang dilakukan oleh Joaquin et al (2002), juga didapatkan hasil korelasi negatif antara tekanan darah sistolik $(-0,21)$ dan diastolik $(-0,47)$ dengan kreatinin. ${ }^{25}$ Penelitian yang dilakukan Farina (2012), didapatkan nilai $p=0,80$ atau bisa dikatakan bahwa tidak ada hubungan yang signifikan antara nilai kreatinin pada ibu lahir normal dengan preeklamsi. $^{26}$

Tidak terdapatnya hubungan yang bermakna pada penelitian ini bisa dikarenakan usia kehamilan yang diatas 34 minggu. Pada preeklamsi onset lambat biasanya derajat keparahan preeklamsi lebih rendah dibanding dengan preeklamsi onset cepat sehingga kerusakan organ yang terjadi masih minimal. ${ }^{27,28}$ Penelitian Chalid et al (2011) juga mendukung bahwa keadaan ibu dan janin lebih buruk pada preeklamsi onset cepat dibandingkan onset lambat karena kadar anti angiogenik (sVEGFR-1) yang lebih tinggi. ${ }^{29}$

Kriteria sampel yang digunakan merupakan ibu yang pertama kali di diagnosis mengalami preeklampsi. karena pada beberapa penelitian, menyatakan bahwa wanita yang pernah mengalami preeklamsi sebelumnya mempunyai resiko yang lebih besar terhadap ibu dan janin. ${ }^{30}$

\section{SIMPULAN}

Tidak terdapat hubungan yang bermakna antara tekanan darah dengan fungsi ginjal pada preeklamsi.

\section{UCAPAN TERIMA KASIH}

Terima kasih kepada semua pihak atas bimbingan, bantuan dan motivasi dalam penelitian ini. 


\section{DAFTAR PUSTAKA}

1. Saifuddin AB. Kematian ibu dan perinatal. Dalam: Saifuddin AB, editor (penyunting). Buku ilmu kebidanan Sarwono Prawirohardjo. Jakarta: PT Bina Pustaka Sarwono Prawirohardjo; 2010.hlm.53-66.

2. Angsar MD. Hipertensi dalam kehamilan. Dalam: Saifuddin AB, editor (penyunting). Buku ilmu kebidanan Sarwono Prawirohardjo. Jakarta: PT Bina Pustaka Sarwono Prawirohardjo; 2010.hlm.530-61

3. UNICEF. Maternal health. 2014 (diunduh 29 Desember 2014). Tersedia dari: http://data.unicef. org/maternal-health/maternal-mortality.

4. Kilembe FD. Hypertensive disorders of pregnancy: prevalence, maternal complications and perinatal outcomes at Lilongwe Central Hospital (tesis). Malawi: Norway; 2004

5. Suwanti, Wibowo EP, Safitri NA. Hubungan tekanan darah dan paritas dengan kejadian Eklampsia di ruang bersalin RSUP NTB tahun 2012. Media Bina IImiah. 2014;8(1):25-30.

6. BMJ Best Practice. 2015 (diunduh 3 Februari 2015). Tersedia dari: http://bestpractice.bmj. com/bestpractice/monograph/326/basics/epidemio logy.html.

7. Osungbade KO, Ige OK. Public health perspectives of preeclampsia in developing countries: implication for health system strengthening. Journal of Pregnancy. 2011;2011:

8. Ananth CV, Keyes KM, Wapner RJ. Preeclampsia rates in the United States, 1980-2010: age-period-cohort analysis. BMJ. 2013;347:doi: 10.1136/bmj.f6564.

9. Direktorat Bina Kesehatan Ibu, Ditjen Bina Gizi dan Kesehatan Ibu dan Anak. Upaya percepatan penurunan angka kematian ibu.: Kementrian Kesehatan Republik Indonesia; 2014.

10. Sulistyowati S. Ekspresi protein MHC klas Ib (HLA-G \& Qa-2) yang rendah terhadap profil Hsp70, VCAM-1 dan MMP-9 pada preeklamsia (disertasi). Surakarta: Fakultas Kedokteran Universitas Sebelas Maret; 2010.

11. Dinas Kesehatan Provinsi Sumatera Barat. Data angka kematian neonatal (AKN) di Sumatera
Barat: dalam laporan kematian bayi. Dinas Kesehatan Provinsi Sumatera Barat. 2014.

12. Jeyabalan A. Epidemiology of preeclampsia: impact of obesity. Nutrition Reviews. 2013;71(Suppl.1):S18-S25.

13. Cunningham FG, Leveno KJ, Bloom SL, Spong CY, Dashe JS, Hoffman BL, Casey BM, Sheffied JS. Williams Obstetrics: 24th Edition. United states: McGraw-Hill Education; 2014.hlm.728-70.

14. Lafayette R. Nephrology The kidney in preeclampsia. Kidney Internasional. 2005;67: 1194-203.

15. Stillman IE, Karumanchi SA. The glomerular injury of preeclampsia. J Am Soc Nephrol. 2007;18: 2281-4

16. Guyton AC, Hall JE. Buku ajar fisiologi kedokteran (terjemahan). Edisi ke-11. Jakarta: EGC; 2008.

17. Effendi I, Markum HMS. Pemeriksaan penunjang pada penyakit ginjal. Dalam: Sudoyo AW, Setiyohadi B, Alwi I, K Simadibrata M, Setiadi S, editor (penyunting). Buku ajar ilmu penyakit dalam. Jilid II. Edisi ke-5. Jakarta: Interna Publishing; 2009.hlm.935-45.

18. Manjareeka M, Nanda S. Elevated levels of serum uric acid, creatinine or urea in preeclamptic women. International Journal of Medical Science and Public Health. 2013;2(1):43-7.

19. Jumaah IAM. Estimation of uric acid, urea, creatinine and creatinine clearance in the serum of preeclamptic women. Kerbala Journal of Pharmaceutical Sciences. 2012;(4):183-9.

20. RSUP Dr. M Djamil Padang. Data rekam medis RSUP Dr. M. Djamil Padang; 2014.

21. Lai J, Poon LCY, Bakalis S, Chiriac R, Nicolaides $\mathrm{KH}$. Systolic, diastolic and mean arterial pressure at 30-33 weeks in the prediction of preeclampsia. Fetal Diagn Ther. 2013;33:173-181.

22. Dorland WAN. Kamus kedokteran Dorland (terjemahan). Edisi ke-31. Jakarta: EGC; 2010.

23. Direktorat Bina Kesehatan Ibu, Ditjen Bina Gizi dan Kesehatan Ibu dan Anak. Upaya percepatan penurunan angka kematian ibu. Kementrian Kesehatan Republik Indonesia; 2014.

24. Wiyono BE. Kadar soluble fms like tyrosine kinase-1 (sFlt-1) dan vascular endothelial growth 
factor (VEGF) pada usia kehamilan 8-20 minggu dengan risiko preeclampsia (tesis). Surakarta: Program Pacasarjana Universitas Sebelas Maret; 2013.

25. Joaquin Z, Armando O, Hugo M. Clinical evolution of hypertension and proteinuria in patients who developed preeclampsia. The Internet Journal Of Gynecology And Obstetrics. 2004;5(1).

26. Farina S. Perbedaan kadar soluble Fms-like tyrosine kinase-1 (sFlt-1) dan placenta growth factor (PIGF) pada preeklampsia dan kehamilan normal (tesis). Surakarta: Program Pascasarjana Universitas Sebelas Maret; 2012.

27. Ekapatria C, Sabarudin U, Sasotya S. Kadar placental growth factor lebih rendah pada preeclampsia awitan dini, sementara tidak ada perbedaan kadar tumor necrosis factor alpha pada preeclampsia awitan dini dan lambat.
Department of Obstetrics and Gynecology Faculty of Medicine University of Padjadjaran/ Dr. Hasan Sadikin Hospital Bandung Research Article. 2012; 36(4):181-4.

28. Fox S. Early and late onset preeclampsia: 2 different entities. Medscape Medical News; 2013.

29. Chalid MT, Patellongi I, Yusuf I. Preeclampsia onset dini dan onset lambat; perbedaan patomekanisme berdasarkan studi klinis dan angiogenesis. JST kesehatan. 2011;1(3): 232-42.

30. Mendilcioglu I, Trak B, Uner M, Umit S, Kucukosmanoglu M. Recurrent preeclampsia and perinatal outcome: a study of women with recurrent preeclampsia compared with women with preeclampsia who remained normotensive during their prior pregnancies. AOGS. 2004;88 (11):1004-48 